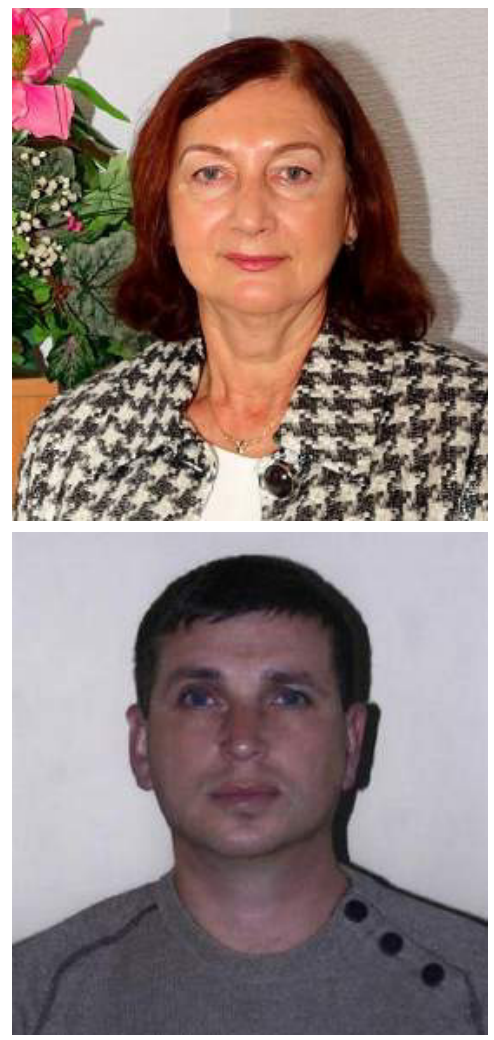

Ірина Медведєва,

доктор педагогічних наук, професор,

Національний педагогічний університет

імені М.П. Драгоманова

(м. Київ)

Iryna Medvedeva,

Doctor of Pedagogical Sciences, Professor,

National Pedagogical Dragomanov University

(Kyiv)

irina.medvedeva06@gmail.com

\author{
Віктор Радзієвський, \\ старший викладач, \\ Національний медичний університет \\ імені О.О. Богомольця \\ (м. Київ)
}

\author{
Viktor Radziyevsky, \\ Teacher, \\ Bogomolets National Medical University \\ (Kyiv)
}

УдК 378: 61-051:796

\title{
ТЕОРЕТИЧНИЙ АНАЛІЗ ПРОБЛЕМИ ФІЗИЧНОГО ВИХОВАННЯ СТУДЕНТІВ МЕДИЧНИХ ВНЗ З УРАХУВАННЯМ ОСОБЛИВОСТЕЙ ÏХ МАЙБУТНЬОЇ ПРОФЕСІЙНОЇ ДІЯЛЬНОСТІ
}

\section{THEORETICAL ANALYSIS OF THE PROBLEM OF PHYSICAL EDUCATION OF MEDICINE STUDENTS: PECULIARITIES OF FUTURE PROFESSIONAL ACTIVITY}

у статті представлено узагальнення результатів наукових досліджень щодо особливостей професійної діяльності лікарів. Показано необхідність їх урахування при побудові та спрямованості занять з фізичного виховання зі студентами. Визначено, що найважливішою серед фізичних якостей у професійній діяльності майбутнього лікаря є фізична витривалість, яка передбачає низьку стомлюваність та високу фізичну працездатність.

Ключові слова: особливості, професійна діяльність, фізична працездатність.

The article presents a generalization of the results of scientific researches concerning the peculiarities of the professional activity of doctors. The necessity of their consideration during the construction and orientation of physical education classes with students is shown. It is determined that the most important among the physical qualities in the professional activity of the future physician is physical endurance, which involves low fatigue and high physical capacity.

The readiness of a modern physician to maintain health should be considered as an essential component of his professional readiness. One of the most important elements of the general culture of a person in general and the future medical worker is the culture of health. The health of the population is an important component of the general culture of a person, which determines the formation, preservation and strengthening of its health. The high level of human health culture implies its harmonious communication with nature and surrounding people. Element of the culture of health is the attentive and correct attitude of man to himself, the desire for self-knowledge, the formation, development and self-improvement of his personality. The culture of health is not only the amount of knowledge, the volume of relevant skills, but also a healthy lifestyle of humanistic orientation. The level of culture of health is determined by the knowledge of the reserve capacity of the body (physical, mental, spiritual) and the ability to correctly use them. For students of medical educational institutions, the importance of a culture of health, a healthy lifestyle, harmonious development of physical qualities increases significantly due to the peculiarities of educational activities and the specifics of the future profession of a doctor. The results of the conducted questionnaire among the I-II students identified the main issues that require their solution in order to significantly improve the educational process of physical education. These include: introducing changes to the curriculum of physical education, namely its theoretical section. It is assumed that the content of the theoretical classes will consist in the formation of knowledge of students about a healthy lifestyle, health status, components of physical health: physical development, physical fitness, motor activity, physical capacity and physical fitness. This will contribute not only to the development of the above-mentioned components of physical health in physical education classes, sectional classes in various sports, independent physical education and sports, while active recreation and leisure, but will also help increase the level of motivation of students to motor activity. The introduction of modern health-improving technologies into practical 
physical education classes, taking into account their future professional activities, will influence the general physical fitness of a young person, his physical fitness, his spiritual and physical development, future achievements in the field of professional activity. The use in the educational process of physical education of means of aerobic orientation requires the introduction of appropriate methods of medical and biological control, which will allow teachers to monitor the state of physical health of students.

The obtained data of the conducted correlation analysis indicate the presence of neuro-emotional stress and decrease in motor activity of the students of the I-II courses, which are the main reason for unsatisfactory dynamics of physical preparedness of students during their studies at the university. In the conditions of physical inactivity, the physical capacity and physical readiness of the future specialist to the future work of work decreases significantly, which in the end does not lead to the successful implementation of the chosen kind of professional activity.

Keywords: peculiarities, professional activity, physical capacity.

В статье представлены обобщения результатов научных исследований, касающихся особенностей профессиональной деятельности врачей. Показана необходимость учета их при построении и направленности занятий с физического воспитания со студентами. Определено, что наиболее важным физическим качеством в профессиональной деятельности будущего врача является физическая выносливость, которая предусматривает низкую утомляемость и высокую физическую работоспособность.

Ключевые слова: особенности, профессиональная деятельность, физическая работоспособность.

Постановка проблеми в загальному вигляді та її зв'язок з важливими науковими та практичними завданнями. Підготовленість сучасного лікаря до здоров'язбереження слід розглядати як найважливішу складову його професійної готовності. Одним із найважливіших елементів загальної культури людини взагалі та майбутнього медичного працівника вважається культура здоров'я. Культура здоров'я - це важливий складовий компонент загальної культури людини, що визначає формування, збереження та зміцнення її здоров'я. Високий рівень культури здоров'я людини передбачає її гармонійне спілкування з природою й оточуючими людьми [2].

Елементом культури здоров'я € уважне і правильне ставлення людини до самої себе, прагнення до самопізнання, формування, розвитку і самовдосконалення своєї особистості. Культура здоров'я - це не тільки сума знань, обсяг відповідних умінь і навичок, але й здоровий спосіб життя гуманістичної орієнтації. Рівень культури здоров'я визначається знанням резервних можливостей організму (фізичних, психічних, духовних) і вмінням правильно використовувати їх. [3]. Для студентів медичних навчальних закладів важливість культури здоров'я, здорового способу життя, гармонійного розвитку фізичних якостей значно зростає у зв'язку з особливостями навчальної діяльності та специфікою майбутньої професії лікаря [1]. Але для розуміння важливості поняття культура здоров'я для медичного працівника, на нашу думку, слід розглянути його компоненти, які відіграють суттєву роль в професійній діяльності. Для успішного виконання професійних обов'язків майбутньому лікарю потрібно мати достатній рівень розвитку всіх фізичних якостей сили, витривалості, гнучкості, швидкості та спритності.

Аналіз останніх досліджень і публікацій, у яких започатковано розв'язання проблеми. Наукові праці Г.В. Власова, О.А. Заплатіна, В.Б. Мандрикова свідчать, що найважливішою серед фізичних якостей у професійній діяльності майбутнього лікаря є фізична витривалість, яка передбачає низьку стомлюваність та високу працездатність [1]. Важливе значення також має координація рухів та м'язова чутливість майбутнього фахівця. Саме розвиток цих фізичних якостей та рухових здібностей, обумовлений специфікою професійної діяльності лікаря, до яких слід віднести:

- ненормований робочий день (нічні та позапланові чергування лікарів та медсестер);

- значні фізичні навантаження (складна робота працівників швидкої допомоги, сімейних та дільничних лікарів, медичних працівників у сільській місцевості, багатогодинні, виснажливі операції, які проводять хірурги та їх асистенти, надання першої медичної допомоги, транспортування хворих чи потерпілих;

- точність рухів та м'язової координації (життєво важлива робота вертебрологів, анестезіологів, кардіо та нейрохірургів, акушерів, травматологів та ортопедів).

У своїй статті Назарук В.Л. підкреслює, що психофізіологічна складова культури здоров'я значною мірою залежить від функціонального стану головного мозку, вона характеризується рівнем і якістю мислення, розвитком уваги і пам'яті, мірою емоційної стійкості, розвитком вольових якостей. Як відомо, в медицині людський фактор має вирішальне значення, тому психофізіологічні особливості майбутнього лікаря, психофізіологічний самоаналіз, оптимізація функціональних станів, які проявляються в професійній діяльності, впливають на ефективність та якість його роботи, а від цього залежить здоров'я та життя пацієнтів.

Крім цього, психофізіологічна складова сприяє розв'язанню завдань професійної спеціалізації та придатності до сфери медичної діяльності, визначенню та формуванню важливих для виконання певної професійної діяльності індивідуально-психологічних якостей медичного працівника [6].

Психофізіологічні складові у сучасному світі є чинниками цілісності чи розладу, стійкості чи дисгармонії, спокою чи тривоги, успіху чи невдач, фізичного та морального благополуччя. На сьогодні будь-який психофізіологічний фактор впливає на діяльність медичного працівника, і кожен з цих факторів залежно від тривалості дії можна віднести до постійних чи тимчасових. Психофізіологічними факторами потенційної небезпеки постійної дії слід вважати: 1) недоліки органів відчуття (дефекти зору, слуху тощо) 2) порушення зв'язків між сенсорними та моторними центрами, внаслідок чого людина не здатна реагувати адекватно на ті чи інші зміни, що сприймаються органами відчуття; 3) дефекти координації рухів (особливо складних рухів та операцій, прийомів тощо); 4) підвищена емоційність; 5) відсутність мотивації до трудової діяльності (незацікавленість в досягненні цілей, невдоволення оплатою праці, монотонність праці, відсутність пізнавального моменту, тобто нецікава робота тощо) [5].

До психофізіологічними факторів потенційної небезпеки тимчасової дії відносяться: 1) недостатність досвіду (поява імовірної помилки, невірні дії, напруження нервово- психічної системи, побоювання допущення помилки); 2) необережність (може призвести до ураження не лише окремої людини, а й всього колективу); 3) втома (розрізняють фізіологічну та психологічну втому); 4) емоційні явища (особливо конфліктні ситуації, душевні стреси, пов'язані з побутом, сім'єю, друзями, керівництвом [5]. Важливість психофізіологічної 
складової культури здоров'я лікаря обумовлена надмірними психофізіологічними та емоційними напруженнями, що пов'язані з особливостями роботи з хворими:

- робота в психіатричних лікарнях з хворими що є соціально небезпечними, агресивними, схильними до суїцидів та імпульсивних дій;

- робота в дитячих будинках, з недієздатними та інтелектуально недорозвинутими дітьми;

- робота з важкими хворими із хронічними хворобами (онкологічними, психіатричними, туберкульозними тощо); робота з наркологічними хворими та хворими на СНІД;

- робота в будинках пристарілих, закладах позбавлення волі, робота військових лікарів в умовах збройних конфліктів та ін.;

- постійна тривога за свою фізичну безпеку [5].

Соціальна складова культури здоров'я медичного працівника передбачає здатність оптимально адаптуватися до соціальних умов, максимально контролювати свої дії та вчинки, вміння володіти собою в будь-яких життєвих ситуаціях та конфліктах, контактувати з пацієнтами, колегами та людьми в соціумі, протистояти негативному впливу оточення; оцінювати власні вчинки; поважати думку інших; прагнення постійно підвищувати рівень комунікативної компетентності; бути ввічливим та уважним у різних життєвих ситуаціях, дотримуватитсь правил безпеки життєдіяльності, здорового способу життя та профілактики захворювань, розвивати почуття приналежності до всього людства [3].

Духовна складова культури здоров'я майбутнього лікаря залежить від його духовного світу, сприйняття та усвідомлення духовної культури людства, освіти, науки, мистецтва, релігії, моралі, етики, свідомості, ментальності, життєвої та самоідентифікації, ставлення до сенсу життя, оцінки реалізації власних здібностей і можливостей у контексті власних ідеалів і світогляду, від духовного потенціалу (моральний аспект здоров'я) - здатність людини розвивати вищі психічні аспекти: альтруїзм, мудрість, інтуїцію тощо $[1,5,6]$. Інформаційна складова культури здоров'я $€$ також важливим фактором впливу на професійну діяльність майбутнього лікаря. Інформація, що передається із різних засобів, може по-різному впливати на людину. Передача негативних образів (інформації) має негативний вплив, призводить до появи різноманітних захворювань і навіть смерті. Протилежним ефектом володіє позитивна інформація чи образ. За вказаними вище причинами система освіти та виховання, а також засоби передачі інформації (книжки, фільми, Інтернет, засоби масової інформації і т. ін.) мають велике значення у формуванні особистості майбутнього лікаря. Таким чином, вищезазначені складові культури здоров'я мають важливий та безпосередній вплив на формування культури здоров'я майбутніх лікарів, на збереження і зміцнення індивідуального здоров'я, на рівень розвитку загальної культури особистості та росту професійної майстерності. Враховуючи важливе значення фізичної складової та її вплив на зміцнення здоров'я та підвищення культури здоров'я майбутніх лікарів постає питання щодо удосконалення навчального процесу з фізичного виховання, побудованого з урахуванням сучасних вимог.

Формування мети статті. Метою статті є формування готовності студентів до майбутньої професійної діяльності на основі вивчення її особливостей, що передбачає впровадження відповідних оздоровчих технологій, які спрямовані на розвиток необхідних фізичних якостей та спроможностей.

Виклад основного матеріалу дослідження 3 повним обґрунтуванням отриманих наукових результатів. Загальний освітянський рівень фізичного виховання у вищих навчальних закладах забезпечуються відповідними програмами, які регламентують стандарти за змістом занять, їх кількості та нормативними вимогами до підготовки студентів. Зміст програмного забезпечення повинен враховувати біологічні, педагогічні та психологічні закономірності керування фізичним станом організму молодої людини в процесі фізичного виховання, враховувати вікові, статеві особливості й обрану майбутню професійну діяльність. Невідповідність цим вимогам у програмах перешкоджає реалізації педагогічного процесу і як наслідок не призводить до здійснення завдань фізичного виховання: підвищення рівня фізичного стану та фізичної підготовленості студентів, фізичної та розумової працездатності, зміцнення здоров'я, зниження рівня захворювань.

Зміцнення здоров'я молодих людей залежить від багатьох чинників, однак вирішальним серед них $€$ ставлення особистості до власного здоров'я. Зростаюча цінність людини як особистості, розширення її світогляду,самореалізація у суспільстві можлива тільки у процесі духовного і фізичного самовдосконалення.

Фізичне виховання у системі вищої освіти реалізується: через взаємозв'язок виховання й навчання; через виховання як процес формування мотивації, а також власний досвід; через навчання як процес набуття знань, умінь та навичок освоєння рухової дії та розвиток фізичних якостей.

Процес навчання з фізичного виховання у вищих навчальних закладах повинен будуватись таким чином, щоб не тільки забезпечити реалізацію завдань, пов'язаних зі зміцненням здоров'я студентів, покращенням рівня їх фізичного стану, підвищенням розумової та фізичної працездатності, але й створенням професійноприкладного ефекту в формуванні оригінальності мислення, здатності до раціональної організації свого особистого часу, внутрішньої дисципліни, об'єктивної оцінки ситуації й ухвалення рішення, наполегливості в досягненні поставлених завдань та мети, умінні спокійно реагувати на невдачі та навіть поразку. Саме на цей новий тип соціалізованої особистості має бути зорієнтована система фізичного виховання.

Необхідною умовою підвищення ефективності навчання з фізичного виховання студентів вищих медичних навчальних закладів, на наш погляд, є формування готовності студентів до майбутньої професійної діяльності на основі вивчення її особливостей та за необхідністю впровадження відповідних оздоровчих технологій, що спрямовані на розвиток необхідних фізичних якостей та їх спроможностей, підвищення рівня фізичної працездатності та фізичної підготовленості засобами фізичного виховання.

Результати проведеного анкетування серед студентів I-II курсів визначили головні питання, що вимагають їх вирішення з метою суттєвого поліпшення навчально-виховного процесу з фізичного виховання. До них відноситься: внесення змін до навчальної програми з фізичного виховання, а саме її теоретичного розділу. Передбачається, що зміст теоретичних занять буде полягати у формуванні знань у студентів про здоровий 
спосіб життя, стан здоров'я, компоненти фізичного здоров'я: фізичний розвиток, фізичну підготовленість, рухову активність, фізичну працездатність та фізичну форму.

Це дозволить сприяти не тільки розвитку вищезазначених компонентів фізичного здоров'я на заняттях з фізичного виховання, секційних заняттях з різних видів спорту, самостійних заняттях фізичною культурою та спортом, під час активного проведення відпочинку та дозвілля, але й буде допомагати підвищенню рівня мотивації у студентів до рухової активності. Впровадження сучасних оздоровчих технологій у практичні заняття з фізичного виховання з урахуванням їх майбутньої професійної діяльності дозволить впливати на загальну фізичну підготовленість молодої людини, її фізичну працездатність, її духовний та фізичний розвиток, майбутні досягнення в сфері професійної діяльності. Використання в навчально-виховному процесі з фізичного виховання засобів аеробної спрямованості потребує впровадження відповідних методів медико-біологічного контролю, які дозволять викладачам спостерігати за станом фізичного здоров'я студентів.

Отримані дані проведеного кореляційного аналізу свідчать про наявність нервово-емоційних стресів та зниження рухової активності студентів I-ІІ курсів, які виступають основною причиною незадовільної динаміки фізичної підготовленості студентів за час їх навчання у вузі. В умовах фізичної бездіяльності фізична працездатність та фізична готовність майбутнього спеціаліста до трудової майбутньої діяльності суттєво зменшується, що в результаті не призводить до успішного виконання обраного виду професійної діяльності.

Висновки і перспективи подальших досліджень. Таким чином, основа наукової концепції фізичного виховання студентської молоді повинна базуватись на принципі оздоровчого спрямування та підпорядкування йому всіх засобів й методів, підготовці кадрів, розробці та впровадженню сучасних технологій в навчальний процес, включаючи самостійні заняття студентів фізичними та спортивними вправами. На наш погляд, до головних напрямів діяльності щодо створення сприятливих умов зміцнення здоров'я студентів відноситься не тільки розробка й впровадження в навчально- виховний процес оздоровчих технологій та їх безпека для здоров'я, але й значну роль слід приділяти вивченню сукупності принципів, прийомів, методів педагогічної роботи, які доповнюють традиційні технології навчання і виховання ознакою здоров'язбереження.

Підвищення ролі цілеспрямованого використання засобів фізичного виховання в період навчання молодої людини у вузі обумовлено значним розумовим та нервово-емоційним навантаженням, малорухомістю, недостатнім рівнем фізичної підготовленості студентів та відсутністю належної мотивації до занять фізичними вправами. Під час розробки програм з фізичного виховання і їх наукового обґрунтування для вищих закладів освіти певного профілю необхідно керуватися принципом індивідуалізації, який передбачає планування фізичних навантажень з урахуванням особливостей фізичного розвитку, стану здоров'я, рівня фізичної підготовленості, профілю навчального закладу. Для студентів медичних навчальних закладів значимість культури здоров'я, здорового способу життя, гармонійного розвитку фізичних якостей значно зростає у зв'язку зі специфікою майбутньої професії лікаря. Результати наукових досліджень свідчать, що до найважливіших складових культури здоров'я необхідних у професійній діяльності майбутнього лікаря відносяться: фізична (біологічна), психофізіологічна, соціальна, духовна та інформаційна складова культури здоров'я. Значна кількість науковців свідчать, що фізичне виховання студентів на сучасному етапі має переборювати значну кількість проблем. Найбільш гострим питанням в цьому напрямі $€$ матеріальне забезпечення навчально-виховного процесу студентів. Крім того, фахівці-педагоги зазначають, що при вивченні питань пов'язаних з удосконаленням навчально-виховного процесу 3 фізичного виховання найчастіше аналізується якась одна сторона даної проблеми - «викладацька» чи «студентська».

На наш погляд, в теорії та практиці фізичного виховання недостатньо вивчені педагогічні умови формування свідомого ставлення студента до занять з фізичного виховання та спорту, яке неможливо створити і реалізувати без найтіснішого особистісного співробітництва між викладачем і студентом.

1. Власов Г. В. Фізичне виховання як основа професійного становлення фахівців медичних закладів / Г.В. Власов // Науковий журнал Педагогіка, психологія та медико-біологічні проблеми фізичного виховання і спорту. - Харків: ХОВНОКУ- ХДАДМ, 2010. - №1. - C. 29-32.

2. Горащук В. П. Теоретичні та методологічні засади формування культури здоров'я школярів : дис...докт. пед. наук: 13.00 .01 / Валерій Павлович Горащук. - Харків, 2004. - 428 с.

3. Литвинова 3. Н. Формирование ценносного отношения личности к культуре здоровья в общеобразовательном процесе вуза : дис. ...канд. пед. наук : 13.00.01 / Зоя Николаевна Литвинова - Ставрополь, 2004. - 192 с.

4. Пильненький В. В. Методичні основи підвищення фізичної підготовленості і фізичного здоров'я студентів методом оздоровчого тренування / В.В.Пильненький, В. А. Леонова. - Миколаїв : Деловая информация, 2004. -91 с.

5. Психічне здоров'я: підруч. / О.С. Чабан, В.Т. Ящук, Я.М. Несторович та ін. - Тернопіль : Укредкнига, $2008 .-480$ с.].

6. Тітов І. Г. Вступ до психофізіології / І. Г. Тітов. - К.: Академвидав, 2011. - 296 с.

\section{Reference}

1. Vlasov G.V. Physical education as a basis for the professional development of specialists in medical institutions / G.V. Vlasov // Scientific journal Pedagogics, psychology and medical-biological problems of physical education and sports. - Kharkiv: HOVNOKU-KDADM, 2010. - №1. - P. 29-32. (Ukrainian).

2. Gorashchuk V.P. Theoretical and methodological principles of formation of the culture of health of schoolchildren: Dis ... doc. ped Sciences: 13.00.01 / Valery Pavlovich Gorashchuk. - Kharkiv, 2004. - 428 p. (Ukrainian).

3. Litvinova Z. N. Formation of the value relation of the personality to the culture of health in the general educational process of the university: diss. ... Candidate ped Sciences: 13.00.01 / Zoya Nikolayevna Litvinova -Stavropol,2004. - 192 p.(Russian).

4. Pilnenky V.V. Methodical bases of increase of physical preparedness and physical health of students by a method of health training / V.V. Pilnenky, VA Leonov. - Mykolaiv: Business Information, 2004. - 91 c.(Ukrainian).

5. Chaban O.S., Yaschuk V.T.,. Nestorovich Ya.M. et al. Mental health: under the arm. / O.S. Chaban, V.T. Yaschuk, Ya.M. Nestorovich et al. - Ternopil: Ukrredkniga, 2008. -480 p. (Ukrainian).

6. Titov I. T. Introduction to psychophysiology / I.G. Titov. - K .: Akademvidav, 2011.- 296 c. (Russian). 